\title{
EFEKTIVITAS MODEL PEMBELAJARAN KOOPERATIF TIPE STAD DITINJAU DARI HASIL BELAJAR IPS SISWA KELAS 4 SD
}

\author{
Firosalia Kristin \\ firosalia.kristin@staff.uksw.edu \\ Program Studi Pendidikan Guru Sekolah Dasar - FKIP - UKSW
}

\begin{abstract}
ABSTRAK
Penelitian ini bertujuan untuk mengetahui efektivitas model pembelajaran STAD dalam meningkatkan hasil belajar IPS siswa kelas IV SD Negeri Duyungan 2 Sragen. Jenis penelitan ini adalah eksperimen dengan desain penelitian two group pre test post test design. Populasi dan sampel adalah siswa kelas 4 SD Negeri Duyungan 2 Sragen. Teknik pengumpulan data dengan tes tertulis. Teknik analisis data menggunakan Uji-t. Hasil penelitian yang diperoleh bahwa model pembelajaran STAD lebih efektif dibandingkan model konvensional dalam meningkatkan hasil belajar IPS. Hal itu dibuktikan dari data yang diperoleh bahwa $t_{\text {hitung }}>t$ tabel, yaitu 3,392 > 2,000.
\end{abstract}

Kata kunci : STAD, Hasil Belajar

\section{PENDAHULUAN}

Pendidikan merupakan hal yang penting dalam kehidupan manusia. Setiap manusia mempunyai hak yang sama untuk memperoleh pendidikan dan berharap untuk selalu berkembang dalam pendidikan. Melalui pendidikan seseorang dapat memperoleh pengetahuan yang luas.

Pendidikan di era globalisasi sekarang ini membuat manusia dapat dengan mudah mengakses beragam informasi. Dengan kemajuan ilmu pengetahuan dan teknologi manusia dapat memperoleh berbagai informasi di bidang tertentu. Globalisasi mendatangkan manfaat bagi manusia. Namun, manusia juga perlu mencermati dan menyikapi hal ini dengan bijak. Salah satu caranya adalah melalui penanaman nilai dan norma. Hal ini dapat dilakukan melalui pendidikan. Pendidikan merupakan cara untuk memberikan pemahaman mengenai konsep dari nilai dan norma yang penting di masyarakat. Sebaiknya, pendidikan ditanamkan semenjak dini. Selain itu, pendidikan juga merupakan bekal bagi si anak di masa depan. 
Peningkatan kualitas sumber daya manusia di Indonesia terus diupayakan. Salah satu upaya dalam peningkatan kualitas tersebut yaitu melalui pendidikan. Pendidikan yang merupakan ujung tombak dalam pengembangan sumber daya manusia harus bisa berperan aktif dalam meningkatkan kualitas dan juga kuantitas. Upaya pengembangan pendidikan tersebut harus sesuai dengan proses pengajaran yang tepat agar anak didik dapat menerima pelajaran dengan baik.

Proses pengajaran agar lebih menarik dan ada kerjasama dengan siswa, maka perlu merubah pembelajaran dari paradigma lama dengan paradigma baru sehingga dapat meningkatkan kreativitas siswa dalam berpikir, keaktifan dan antusiasme siswa dalam belajar. Proses pembelajaran yang satu arah di rubah menjadi dua arah atau banyak arah sehingga siswa dapat terlibat secara langsung.

Komponen dalam kegiatan pembelajaran yaitu kurikulum, guru/pendidik, model pembelajaran, siswa. Dimana semua komponen tersebut saling terkait. Berdasarkan hal tersebut pendidik dituntut harus mampu mengajar dengan berbagai pendekatan dan model pembelajaran yang bervariasi. Dengan demikian siswa dapat mengikuti proses pembelajaran dengan menyenangkan, mengingat bahwa siswa bukan hanya sebagai objek tetapi juga merupakan subjek dalam pembelajaran.

Fenomena yang terjadi saat ini, siswa hanya sebagai pendengar yang baik. Guru yang lebih berperan aktif dalam pembelajaran. Seperti yang terlihat di SD Negeri Duyungan 2 Sragen. Pada mata pelajaran IPS siswa hanya sebagai pendengar yang baik, guru yang lebih aktif. Menurut observasi peneliti, ada kemungkinan karena gurunya sudah hampir purna tugas sehingga malas untuk mencari model pembelajaran yang kreatif. Guru membacakan materi pelajaran, sesekali menulis di papan tulis, sesekali siswa diminta untuk mengerjakan soal-soal di LKS. Terlihat siswa merasa jenuh dan bosan saat mengikuti pembelajaran di kelas. Hal tersebut juga berpengaruh pada hasil belajar yang diperoleh siswa. Dari studi dokumentasi, diperoleh data sebanyak 3 siswa memperoleh nilai 70 dari 20 jumlah keseluruhan, dan 17 siswa rata-rata memperoleh nilai dibawah 50.

Berdasarkan latar belakang tersebut, peneliti tertarik untuk mencoba menerepkan model pembelajaran kooperatif tipe $S T A D$ dalam pembelajaran di kelas. Student Teams Achievement Division (STAD) merupakan salah satu metode atau pendekatan dalam pembelajaran kooperatif yang sederhana dan baik untuk guru yang baru mulai menggunakan pendekatan kooperatif dalam kelas, STAD juga merupakan suatu metode pembelajaran kooperatif yang efektif.

Berdasarkan latar belakang diatas, maka rumusan masalah dalam penelitian ini adalah apakah model pembelajaran kooperatif tipe STAD lebih efektif dibandikan dengan model konvensional terhadap hasil belajar IPS siswa kelas 4SD. 


\section{KAJIAN PUSTAKA}

\section{Hakikat IPS SD}

Rumusan tentang pengertian IPS telah banyak dikemukakan oleh para ahli IPS atau social studies. Di sekolah-sekolah Amerika pengajaran IPS dikenal dengan social studies. Jadi, istilah IPS merupakan terjemahan social studies. Dengan demikian IPS dapat diartikan dengan "penelaahan atau kajian tentang masyarakat". Dalam mengkaji masyarakat, guru dapat melakukan kajian dari berbagai perspektif sosial, seperti kajian melalui pengajaran sejarah, geografi, ekonomi, sosiologi, antropologi, politik-pemerintahan, dan aspek psikologi sosial yang disederhanakan untuk mencapai tujuan pembelajaran. Berikut pengertian IPS yang dikemukakan oleh para ahli (Nadir, dkk, 2009: 10) :

a) Moeljono Cokrodikardjo mengemukakan bahwa IPS adalah pewujudan dari suatu perdekatan interdisipliner dari ilmu sosial. Ia merupakan integrasi dari berbagai cabang ilmu sosial yakni sosiologi, antropologi, budaya, psikologi, sejarah, geograpi, ekonomi, ilmu politik dan ekologi manusia, yang diformulasikan untuk untuk tujuan intruksional dengan materi dan tujuan yang disederhanakan agar mudah dipelajari.

b) Nu'man Soemantri menyatakan bahwa IPS merupakan pelajaran ilmuilmu sosial yang disederhanakan untuk pendidikan tingkat SD, SLTP, dan SLTA. Penyederhanaan mengandung arti: a) menurunkan tingkat kesukaran ilmu-ilmu sosial yang biasanya dipelajari di universitas menjadi pelajaran yang sesuai dengan kematangan berfikir siswa siswi sekolah dasar dan lajutan, b) mempertautkan dan memadukan bahan aneka cabang ilmu-ilmu sosial dan kehidupan masyarkat sehingga menjadi pelajaran yang mudah dicerna.

c) S. Nasution mendefinisikan IPS sebagai pelajaran yang merupakan fusi atau paduan sejumlah mata pelajaran sosial. Dinyatakan bahwa IPS merupakan bagian kurikulum sekolah yang berhubungan dengan peran manusia dalam masyarakat yang terdiri atas berbagai subjek sejarah, ekonomi, geograpi, sosiologi, antropologi, dan psikologi sosial.

Jadi pengertian IPS adalah ilmu yang mempelajari berbagai displin ilmu yang terpadu berkaitan dengan manusia dan lingkungannya.

Tujuan dari pendidikan IPS adalah untuk mendidik dan memberi bekal kemampuan dasar kepada siswa untuk mengembangkan diri sesuai dengan bakat, minat, kemampuan dan lingkungannya, serta berbagai bekal bagi siswa untuk melanjutkan pendidikan ke jenjang yang lebih tinggi ( Etin Solihatin \& Raharjo, 2005: 15). 


\section{Model Pembelajaran Kooperatif Tipe STAD}

Student Teams Achievement Division (STAD) merupakan salah satu metode atau pendekatan dalam pembelajaran kooperatif yang sederhana dan baik untuk guru yang baru mulai menggunakan pendekatan kooperatif dalam kelas, STAD juga merupakan suatu metode pembelajaran kooperatif yang efektif.

Pembelajaran kooperatif tipe $S T A D$ dikembangkan oleh Slavin dan temantemannya di Universitas John Hopkin. Guru yang menggunakan STAD, juga mengacu kepada belajar kelompok murid, menyajikan informasi akademik baru kepada murid setiap minggu menggunakan presentasi verbal atau teks. Guru membagi murid menjadi kelompok-kelompok kecil yang terdiri dari 4-5 orang dan terdiri laki-laki dan perempuan yang berasal dari berbagai suku, memiliki kemampuan tinggi, sedang, rendah.

Slavin (2011: 21) Student Teams Achievement Division (STAD), siswa ditempatkan ke tim-tim belajar yang beranggotakan empat orang yang bercampur tingkat kinerja, jenis kelamin, dan suku bangsa. Guru menyajikan pelajaran kemudian siswa bekerja dalam kelompok kecil dan memastikan semua anggota sudah memahami tentang pelajaran yang diberikan.

Komponen STAD menurut Slavin (2011: 32) adalah sebagai berikut: (1)Presentasi kelas. Presentasi kelas dalam $S T A D$ berbeda dari cara pengajaran yang biasa. Masing-masing kelompok mempresentasikan hasil diskusi kelompok mereka. Murid harus betul-betul memperhatikan presentasi ini karena dalam presentasi terdapat materi yang dapat membantu untuk mengerjakan kuis yang diadakan setelah pembelajaran. (2)Belajar dalam tim. Murid dibagi menjadi beberapa kelompok, tiap kelompok terdiri dari 4-5 orang dimana mereka mengerjakan tugas yang diberikan. Jika ada kesulitan murid yang merasa mampu membantu murid yang kesulitan. (3)Tes individu yang dilaksanakan setelah pembelajaran. (4)Skor pengembangan individu. Skor yang didapatkan dari hasil tes selanjutnya dicatat oleh guru untuk dibandingkan dengan hasil prestasi sebelumnya. Skor tim diperoleh dengan menambahkan skor peningkatan semua anggota dalam 1 tim. Nilai rata-rata diperoleh dengan membagi jumlah skor penambahan dibagi jumlah anggota tim. (5)Penghargaan tim. Penghargaan didasarkan nilai rata-rata tim dimana dapat memotivasi mereka.

\section{Hasil Belajar}

Belajar adalah suatu perubahan tingkah laku yang relatif permanen sebagai hasil dari pengalaman. Dalam konteks sekolah, belajar adalah suatu proses usaha yang dilakukan siswa untuk memperoleh suatu perubahan tingkah laku yang baru 
secara keseluruhan, sebagai hasil pengalaman siswa sendiri dalam interaksi dengan lingkungannya.

Menurut Slameto (2003: 3), hasil belajar yaitu perubahan yang terjadi dalam diri seseorang, berkesinambungan, dan tidak statis. Satu perubahan yang terjadi akan menyebabkan perubahan berikutnya dan akan berguna bagi kehidupan ataupun proses belajar berikutnya. Sedangkan menurut Purwanto (2011: 44) hasil belajar merupakan hasil yang diperoleh akibat dari suatu aktivitas yang dilakukan oleh seseorang.

Hasil belajar berarti hasil yang diperoleh seseorang dari aktivitas yang dilakukan dan mengakibatkan terjadinya perubahan tingkah laku.

\section{METODE PENELITIAN}

Penelitian ini merupakan penelitian eksperimen. Penelitian eksperimental (experimental rasearch), yang bertujuan untuk meneliti pengaruh dari suatu perlakuan tertentu terhadap gejala suatu kelompok lain yang sama tetapi diberi perlakuan yang berbeda. Penelitian eksperimental dilakukan pada kelas yang akan dilakukan perlakuan (treatment) atau yang disebut kelas eksperimen (experimental group) dan kelas pembanding yang disebut dengan kelompok kontrol (control group). Desain penelitian eksperimen yang digunakan adalah two group pre test post test design.

Populasi dan sampel penelitian ini adalah Siswa kelas 4 di SD Negeri Duyungan 2 Sragen. Sedangkan teknik pengumpulan datanya menggunakan teknik tes. Teknik tes yang digunakan dalam penelitian ini adalah tes tertulis.

\section{HASIL DAN PEMBAHASAN}

Berdasarkan hasil analisis diskriptif (data pretest dan posttest), nilai hasil belajar baik pada kelas eksperimen maupun pada kelas kontrol menunjukan adanya perbedaan. Hasil pretest kelas eksperimen menunjukan bahwa nilai rerata (mean) hasil belajar adalah 54,45; sedangkan untuk kelas kontrol menunjukan bahwa nilai rerata (mean) hasil belajar adalah 50,85. Sedangkan untuk hasil posttest kelas eksperimen menunjukan bahwa rerata (mean) hasil belajar adalah 75,55, dan untuk kelas kontrol menunjukan bahwa nilai rerata (mean) hasil belajar adalah 64,25.

Maka dari itu, bila dilihat dari besarnya nilai rerata data pretest dan posttest hasil belajar, dapat dilihat bahwa peningkatan kelas eksperimen sebesar 21,1, sedankan kelas kontrol sebesar 13,4. Dengan demikian dapat disimpulkan bahwa ada peningkatan rerata skor untuk kedua nilai tersebut, kelas eksperimen lebih besar daripada peningkatan yang terjadi pada kelas kontrol. Hal ini berarti penggunaan 
Model pembelajaran Kooperatif tipe STAD lebih efektif meningkatkan hasil belajar IPS dibandingkan menggunakan model konvensional.

Hasil dari analisis diskriptif lebih dipertegas lagi dengan hasil pengujian hipotesis. Hasil pengujian hipotesis diperoleh thitung $=3,392$. Pada taraf signifikansi 0,05 diperoleh nilai ttabel $=2,000$. Berarti thitung $>$ ttabel $(3,392>$ 2,000). Dengan demikian menunjukan bahwa model pembelajaran kooperatif tipe STAD lebih efektif dibandingkan model konvensional.

Proses pembelajaran yang berlangsung dengan menggunakan model pembelajaran kooperatif tipe $S T A D$ membuat siswa merasa senang dalam mengikuti pembelajaran di kelas. Siswa lebih tertarik dan termotivasi untuk belajar tentang materi IPS. Selain itu guru bukan sebagai subjek pembelajar tetapi sebagai fasilitator yang membantu siswa yang mengalami kesulitan dalam belajar, memotivasi dan memfasilitasi siswa dalam belajar. Dengan demikian siswa terbantu untuk mengkonstruk sendiri tentang pengetahuan yang diperoleh melalui pengalaman belajar yang dialaminya.

\section{SIMPULAN}

Berdasarkan hasil penelitian yang telah diperoleh dengan analisis data dan pengujian hipotesis, maka dapat ditarik kesimpulan bahwa model Pembelajaran kooperatif tipe STAD lebih efektif dibandingkan model konvensional untuk meningkatkan hasil belajar IPS siswa kelas 4 SD Negeri Duyungan 2 Sragen. Hasil penelitian menunjukkan bahwa nilai hasil uji-t diperoleh nilai t hitung sebesar 3,392 dan nilai $t$ tabel sebesar 2,000 pada taraf signifikansi sebesar 5\% $(0,05)$.

\section{DAFTAR PUSTAKA}

Etin Solihatin \& Raharjo. 2005. Cooperative Learning, Analisis Model Pembelajaran IPS. Jakarta: Bumi Aksara.

Nadir, dkk.2009. Ilmu Pengetahuan Sosial 1, Ed.1. Surabaya: Amanah Pustaka.

Purwanto. (2011). Evaluasi hasil belajar. Yogyakarta: Pustaka Pelajar

Slavin, Robert E. 2010. Cooperative Learning: teori, Riset dan Praktik.

Slameto. (2003). Belajar dan faktor-faktor yang mempengaruhinya. Jakarta: Rineka Cipta. 